\title{
Editors and contributors
}

\section{Editors}

Keith Laybourn is Professor of History and the Diamond Jubilee Professor of the University of Huddersfield, and a Fellow of the Royal Historical Society. He has known and worked with Chris Wrigley for nearly thirty years. He has written and edited extensively on British labour history, social policy, women's history, the history of voluntary organisations and policing history. He published The General Strike with Manchester University Press in 1993 and many books on the rise of labour, including The Rise of Labour (Arnold, 1988) and Under the Red Flag (Sutton, 1999). With David Taylor he published Policing in England and Wales 19I8-1939: The Fed, the Flying Squad and Forensics (Palgrave, 20II) and his own most recent book is The Battle for the Roads of Britain: Police, Motorists and the Law c. I89os-1970 (Palgrave, 2015). He edited the Annual Bulletin of Historical Literature (1999-2010) for the Historical Association, is an Honorary Fellow of the Historical Association and is President of the Society for the Study of Labour History (20I2-).

John Shepherd is Visiting Professor of Modern History at the University of Huddersfield and a Fellow of the Royal Historical Society. He has worked in polytechnics and universities and was Visiting Professor, Cofounder and Joint Director of the Labour History Research Unit at Anglia Ruskin University, Cambridge. His publications include George Lansbury: At the Heart of Old Labour (Oxford University Press, 2002, 2004), Britain's First Labour Government, with Keith Laybourn (Palgrave, 2006, 2013) and Crisis? What Crisis? The Callaghan Government and the 'Winter of Discontent' (Manchester University Press, 2013, 2015). He edited with Chris 
Wrigley On the Move: Essays in Labour and Transport History Presented to Philip Bagwell (The Hambledon Press, 1991) and also jointly edited with Jonathan Davis and Chris Wrigley Britain's Second Labour Government 1929-3I: A Reappraisal (Manchester University Press, 20II). Currently he is completing for Manchester University Press a biography of Dr Jon Cruddas MP, former Shadow Cabinet member and Head of Labour's Policy Review, 20I2-I5.

\section{Contributors}

Joan Allen is Senior Lecturer in Modern British History at the University of Newcastle. She is a member of many history committees, including the Steering Committee History UK, the Executive Committee of Newspaper and Periodical History, the Library Committee of the Institute of Historical Research and the Executive Committee of the Society for the Study of Labour History. She has research interests in Victorian society and politics, nineteenth-century British radicalism, and especially Chartism, for which she is the co-convenor of the Chartist Conference. She has written many articles and published a range of books, including the monograph Joseph Cowen and Popular Radicalism in Tyneside I829-1900 (Merlin Press, 2007); she has also edited a number of books, including (with Owen Ashton) Papers for the People: A Study of the Chartist Press (Merlin Press, 2005) and (with Richard Allen) Faith in Our Fathers: Popular Culture and Belief in Post-Reformation England, Ireland and Wales (Cambridge Scholars, 2009). She is currently writing a book on the Catholic press.

Kenneth D. Brown is Professor Emeritus in History at Queen's University Belfast and was Pro-Vice-Chancellor from 200I to 2009, when he retired. He has ranged widely over British labour, business and religious history and written on British and Japanese economic and social development. He is currently finishing a new biography of Herbert Gladstone. Among his publications are Essays in Anti-Labour History (Macmillan, 1974), A Social History of the Nonconformist Ministry in England and Wales, I800-1930 (Oxford University Press, 1988), The British Toy Business: A History Since I700 (Hambledon Continuum, 1996) and Factory of Dreams: A History of Meccano Ltd, 190I-I979 (Crucible, 2007).

Malcolm Chase is Professor of Social History at the University of Leeds. He has written extensively on British Labour history and Chartism and is currently researching self-improvement, popular reform and public good in the mid-nineteenth century. His publications include The People's Farm: English Radical Agrarianism, I775-I840 (Oxford University Press, 1988), Early Trade Unionism: Fraternity, Skill and the Politics of Labour (Ashgate, 200o), Chartism: A New History (Manchester University Press, 2007) and 
I820: Disorder and Stability in the United Kingdom (Manchester University Press, 2013).

Dick Geary is Emeritus Professor in History at the University of Nottingham and has specialised in European labour movements and the intellectual history of Marxism. He has specialised in German history and is also researching the history of slavery. His publications include European Labour Protest 1848-I929 (Croom Helm, 198I), Karl Kautsky (Manchester University Press, 1987), European Labour Politics from 1900 to the Depression (Palgrave, 199I), Hitler and Nazism (Routledge, 1993) and (with Stephen Hodkinson), Slaves and Religions in Graeco-Roman Antiquity and Modern Brazil (Cambridge Scholars, 20Io).

Kevin Jefferys was formerly Professor of Contemporary History at Plymouth University. He is an expert in British labour history, Churchill and the Second World War, and the history of sport in Britain. He has published many articles and books. The latter include Churchill Coalition and Wartime Politics 1940-1945 (Manchester University Press, 199I), Retreat from the New Jerusalem: British Politics 195I-1964 (St Martin's Press, 1997), Anthony Crosland (Metro Books, 1999), Finest and Darkest Hours: The Decisive Events in British Politics from Churchill to Blair (Atlantic Books, 2002), Politics and the People: A History of British Democracy Since I9I8 (Atlantic Books, 2007) and Sport and Politics in Modern Britain: The Road to 2012 (Palgrave Macmillan, 2012), for which he won the Lord Aberdere Literary Prize in 2013.

Nicole Robertson is Senior Lecturer at Sheffield Hallam University, where she specialises in nineteenth- and twentieth-century British history, researching the co-operative movement, white-collar workers, the history of retailing and consumer society. Her current research focuses on workplace politics among white-collar workers in Britain between 1920 and 1970, and examines the rise of the British workplace, unemployment, gender, politics, professionalisation and identity. She is a former $\mathrm{PhD}$ student of Chris Wrigley. Her publications include Consumerism and the Co-operative Movement in Modern British History: Taking Stock (edited with Lawrence Black; Manchester University Press, 2009), The Co-operative Movement in Britain: Minding Their Own Business (Ashgate, 20Io), a contribution to the The Second Labour Government 1929-3I: A Reappraisal (Manchester University Press, 20II) and articles in Business History (2012) and Labor History (20I4).

Janet Shepherd writes on modern social history. She gained her $\mathrm{PhD}$ at London Guildhall University (part-time) on pauper education in nineteenth-century England and has taught in London, Cyprus and 
Cambridge. She has contributed nine entries to the Oxford Dictionary of National Biography (Oxford University Press, 2004) and her recent publications include The I95os Home (Amberley Publishing, 20I7), Britain in the Ig20s (Shire, 2010), Britain in the I970s (Shire, 2012) and I950s Childhood (Shire, 20I4), all jointly with John Shepherd. Her current research interests centre on modern British social history and children's literature. She is the daughter of Dr Ernest Seeley (1900-89), General Secretary of the ATTI union and a leading member of the Progressive League for fifty years.

Andrew Thorpe is Pro-Vice-Chancellor and Executive Dean (Humanities) and Professor of Modern British History at the University of Exeter. Among his publications are The British General Election of I93I (Clarendon Press, 199I), The British Communist Party and Moscow, 1920-1943 (Manchester University Press, 2000), Parties at War: Political Organization in Second World War Britain (Oxford University Press, 2009) and $A$ History of the British Labour Party (Palgrave Macmillan, 4th edition 2015). His most recent publication, co-edited with Richard Toye, is Parliament and Politics in the Age of Asquith and Lloyd George: The Diaries of Cecil Harmsworth, MP, 1909-1922 (Royal Historical Society, 2016). He is currently working on the life and political career of Labour leader Arthur Henderson (1863-1935).

Noel Whiteside is Professor of Comparative Public Policy at the University of Warwick and has been awarded a Visiting Professorship at SSEE (Smith School of Enterprise and Environment), Oxford University. She is a contemporary historian of social and public policy development with specific interests in labour markets and the construction of social dependency in comparative (European) perspective. Her recent books include Pension Security in the Twenty-First Century: Redrawing the Public-Private Divide (edited with Gordon L. Clark; Oxford University Press, 200o, 2005), Britain's Pensions Crisis: History and Policy (edited with Hugh Pemberton and Pat Thane; Oxford University Press, 2006), Transforming European Employment Policy: Labour Market Transitions and the Promotion of Capability (edited with Ralf Rogowski and Robert Salais; Edward Elgar, 20II), Casual Labour (Oxford University Press, 1986) and Bad Times: Unemployment in British Social and Political History (Faber \& Faber, 199I). She has also contributed to three of Chris Wrigley's edited books.

Matthew Worley is Professor of Modern History at the University of Reading specialising in twentieth-century British politics. His particular interest is in the inter-war British labour movement and he has written on the Labour Party, communism in Britain and Europe, and the far right. He is currently researching the link between politics and youth 
culture in the I970s and I980s, paving the way for a book to be published by Cambridge University Press in 2017. His books include Class Against Class: The Communist Party in Britain Between the Wars (I. B. Tauris, 200I), Labour Inside the Gate: A History of the Labour Party Between the Wars (I. B. Tauris, 2005), Oswald Mosley and the New Party (Palgrave Macmillan, 20Io) and (with E. Smith) Against the Grain: The British Far Left from 1956 (Manchester University Press, 20I4). 